\title{
Serotonin regulates osteoblast proliferation and function in vitro
}

\author{
S.Q. Dai ${ }^{1 *}$, L.P. $Y u^{1 *}$, X. Shi ${ }^{2}$, H. $\mathrm{Wu}^{3}$, P. Shao ${ }^{1}$, G.Y. Yin ${ }^{1}$ and Y.Z. Wei ${ }^{1}$ \\ ${ }^{1}$ Department of Orthopedic Surgery, The First Affiliated Hospital, Nanjing Medical University, Nanjing, Jiangsu, China \\ ${ }^{2}$ Department of Obstetrics and Gynecology, The First Affiliated Hospital, Nanjing Medical University, Nanjing, Jiangsu, China \\ ${ }^{3}$ Emergency Department, The First Affiliated Hospital, Soochow University, Suzhou, China
}

\begin{abstract}
The monoamine serotonin (5-hydroxytryptamine, 5-HT), a well-known neurotransmitter, also has important functions outside the central nervous system. The objective of this study was to investigate the role of 5-HT in the proliferation, differentiation, and function of osteoblasts in vitro. We treated rat primary calvarial osteoblasts with various concentrations of $5-\mathrm{HT}$ (1 nM to $10 \mu \mathrm{M})$ and assessed the rate of osteoblast proliferation, expression levels of osteoblast-specific proteins and genes, and the ability to form mineralized nodules. Next, we detected which 5-HT receptor subtypes were expressed in rat osteoblasts at different stages of osteoblast differentiation. We found that 5-HT could inhibit osteoblast proliferation, differentiation, and mineralization at low concentrations, but this inhibitory effect was mitigated at relatively high concentrations. Six of the 5-HT receptor subtypes $\left(5-\mathrm{HT}_{1 \mathrm{~A}}, 5-\mathrm{HT}_{1 \mathrm{~B}}, 5-\mathrm{HT}_{1 \mathrm{D}}, 5-\mathrm{HT}_{2 \mathrm{~A}}, 5-\mathrm{HT}_{2 \mathrm{~B}}\right.$, and $\left.5-\mathrm{HT}_{2 \mathrm{C}}\right)$ were found to exist in rat osteoblasts. Of these, 5$\mathrm{HT}_{2 \mathrm{~A}}$ and $5-\mathrm{HT}_{1 \mathrm{~B}}$ receptors had the highest expression levels, at both early and late stages of differentiation. Our results indicated that $5-\mathrm{HT}$ can regulate osteoblast proliferation and function in vitro.
\end{abstract}

Key words: Serotonin; Osteoblast; Proliferation; Differentiation; 5-HT receptors; 5-HT

\section{Introduction}

Bone remodeling is a highly regulated process that requires a tight coupling of bone formation with resorption to maintain skeletal mass. Imbalances in bone formation and resorption lead to pathological conditions such as osteopenia, osteoporosis, and osteomalacia. Bone mass and osteoblast activity, as well as proliferation and differentiation of osteoblast precursors, are regulated by many factors, including hormones and locally produced growth factors and cytokines, which respond to hormonal activation (1-4).

In recent years, the neurotransmitter serotonin (also known as 5-hydroxytryptamine, 5-HT) was discovered to be involved in bone metabolism. Clinical observations suggest that $5-\mathrm{HT}$ might be associated with bone mass. Selective 5-HT reuptake inhibitors (SSRIs) are routinely used to treat depression in adults (5), children, and adolescents (6-8). SSRIs hinder the 5-HT transporter from taking up 5-HT from the synaptic space, thus increasing extracellular levels of $5-\mathrm{HT}$. It has been reported that patients taking the SSRI fluoxetine appear to have an elevated risk of fracture (9-16). Consistent with this finding, serum 5-HT was reported to be inversely correlated with femoral neck total and trabecular volumetric bone mineral density (7). Functional serotonergic pathways in bones (17-19) may enable 5-HT to influence skeletal biology. These observations suggest that there may be an important relationship between 5-HT and bone remodeling.

Reports of the effects of $5-\mathrm{HT}$ on bone are conflicting. Yadav et al. (20) reported that 5-HT acted on osteoblasts via the $5-\mathrm{HT}_{1 \mathrm{~B}}$ receptor to inhibit their proliferation, while many other researchers found that $5-\mathrm{HT}$ had an opposite effect $(18,19,21-26)$. The reason for this inconsistency is unknown. The purpose of the present study was to explore the possible physiological roles of 5-HT in bone metabolism. Our data suggest that 5-HT plays a significant role in the regulation of bone biology in vitro.

\section{Material and Methods}

\section{Ethics statement}

All experimental procedures involving animals were performed in accordance with the protocols approved by the Experimental Animal Ethics Committee of Nanjing

Correspondence: G.Y. Yin and/or Y.Z. Wei, Department of Orthopedic Surgery, The First Affiliated Hospital, Nanjing Medical University, 300 Guangzhou Road, Nanjing, Jiangsu 210029, China. E-mail: guoyongyin001@sina.com and/or wyzljm@163.com

${ }^{*}$ These authors contributed equally to this study.

Received October 3, 2013. Accepted May 22, 2014. First published online August 1, 2014. 
Medical University, China, and conformed to the Guide for the Care and Use of Laboratory Animals of the National Institutes of Health (USA). All efforts were made to minimize suffering.

\section{Isolation, culture, and preparation of rat calvarial osteoblasts}

Primary osteoblasts were isolated by collagenase digestion from calvariae of Sprague-Dawley rats that were 1-2 days old. Osteoblasts were grown in complete medium, i.e., $\alpha$-minimal essential medium (HyClone, USA) supplemented with $10 \%$ fetal bovine serum (FBS; HyClone), $100 \mathrm{U} / \mathrm{mL}$ penicillin, and $0.1 \mathrm{mg} / \mathrm{mL}$ streptomycin (Gibco, USA). Because FBS is known to contain relatively high levels of $5-\mathrm{HT}$ from platelet lysis (approximately $300 \mathrm{ng} / \mathrm{mL}$ by enzyme-linked immunosorbent assay, ELISA) (27), 5-HT was stripped from the FBS by incubation with dextran-coated charcoal (Sigma, USA). The concentration after treatment was confirmed by high performance liquid chromatography to be below $1 \mathrm{pM}$ in the medium containing $10 \%$ FBS. All the operations involving 5-HT needed to be protected from light, because $5-\mathrm{HT}$ is an unstable compound and decomposes quickly.

Osteoblasts at passage 3 were used to perform all cell studies and were divided into six groups, which were cultured in the presence of various concentrations of 5-HT (Sigma): $0 \mathrm{M}$ (control group) and $1 \mathrm{nM}, 10 \mathrm{nM}, 100 \mathrm{nM}$, $1 \mu \mathrm{M}$, and $10 \mu \mathrm{M}$ (experimental groups). After attachment, the osteoblasts were serum starved for $12 \mathrm{~h}$ prior to experiments. 5-HT was then added, beginning on day 1 . After the cells reached confluence, at approximately day 5 , the complete medium was replaced with a differentiation medium (complete medium containing $50 \mu \mathrm{g} / \mathrm{mL}$ ascorbic acid, and $10 \mathrm{mM} \beta$-glycerophosphate, Sigma) for appropriate mineralization.

\section{Cell proliferation assay}

Cell proliferation was determined using the Cell Counting Kit-8 (CCK-8; Dojindo, Japan) as described elsewhere (28). Osteoblasts of passage 3 were cultured for 2 days with 5-HT prior to CCK-8 assay. Absorbance (optical density, OD) at $450 \mathrm{~nm}$ was measured with a microplate spectrophotometer (BioTek, USA). Cell number was correlated with OD values. The cell proliferation rate was calculated as a percentage as follows: $\left(O D_{\text {serotonin }}-O D_{\text {blank }}\right) /\left(O D_{\text {control }}-O D_{\text {blank }}\right) \times 100$.

\section{Quantitative real-time RT-PCR analysis}

The level of type I collagen (col1a1) mRNA was examined by quantitative real-time reverse transcription polymerase chain reaction (qRT-PCR) analysis on day 5 . RNA isolated from cells cultured with $5-\mathrm{HT}$ was concentrated using a NanoDrop 2000 microvolume spectrophotometer (Thermo Scientific, USA), and cDNA was synthesized using M-MuLV reverse transcriptase (Fermentas, USA). PCR was performed using a Power
SYBR Green PCR Master Mix (Applied Biosystems, USA) on a Real-Time Thermal Cycler apparatus (Mastercycler ep realplex; Eppendorf, Germany). The relative level of expression for the target gene was normalized by the housekeeping gene GAPDH and calculated using the $2^{-\Delta \Delta C t}$ relative quantification method, as described previously (29). Primer sequences for each gene are listed in Table 1.

For assessment of 5-HT receptor mRNA expression, we selected osteoblasts from the control group at day 5 and day 15 to represent early and late stages of osteoblast differentiation, respectively. When the program was completed, we analyzed the real-time PCR products of $5-\mathrm{HT}$ receptors by electrophoresis on a $1.5 \%$ agarose/ Tris-acetate-EDTA (TAE) gel and stained them with ethidium bromide to further confirm amplification specificity and amplicon size.

\section{Western blot analysis}

To assess alkaline phosphatase (ALP) protein expression, we performed Western blot analysis, as described elsewhere (30). In brief, proteins were extracted from different experimental groups at day 10 and quantified. Twenty micrograms of supernatant protein samples were subjected to sodium dodecylsulfate-polyacrylamide gel electrophoresis and transferred to Immobilon-P polyvinylidene fluoride (PVDF) membranes (Millipore, USA). Following blocking, immunoblots were incubated with anti-ALP monoclonal antibody (1:10,000; Abcam, UK) overnight at $4^{\circ} \mathrm{C}$. A GAPDH antibody (Sigma) was used as a protein loading control. Blots were then incubated with horseradish peroxidase-conjugated secondary antibody $\left(1: 10,000\right.$; Bioworld, USA) at $37^{\circ} \mathrm{C}$ for $1 \mathrm{~h}$ and visualized using a SuperSignal West Pico chemiluminescence substrate kit (Pierce, USA). The membranes were scanned using a Molecular Imager (Bio-Rad, USA), followed by data analysis using the Image Lab software (Bio-Rad). Data are reported as the protein-to-GAPDH ratio to correct for variations in protein loading.

\section{Alkaline phosphatase activity assay}

ALP activity was assessed at day 10 using a phosphate assay kit (BioAssay Systems, USA), and the assessment was based on the cleavage of p-nitrophenyl phosphate, as described elsewhere (31). The product of the enzyme reaction, p-nitrophenol, was assessed by measuring the absorbance at $405 \mathrm{~nm}$. The protein concentration of each sample was measured using a bicinchoninic acid protein assay reagent kit (Pierce). ALP activity was expressed as the ratio of OD to protein content.

\section{ELISA}

At day 15, the amount of osteocalcin (OCN) released into the culture medium was measured using the commercially available Rat Osteocalcin EIA Kit (BT-490; Biomedical Technologies, USA), in accordance with the 
Table 1. Primer sets used in real-time RT-PCR.

\begin{tabular}{lrcc}
\hline Primer & FW/RV sequence $\left(5^{\prime} \rightarrow 3^{\prime}\right)$ & $\begin{array}{c}\text { Product } \\
\text { length (bp) }\end{array}$ & $\begin{array}{c}\text { Accession No. } \\
(\text { NCBI }\end{array}$ \\
\hline Col1a1 & CTGCCCCTCGCAGGGGTTTG/GCCTGCACATGTGTGGCCGA & 72 & NM_053304.1 \\
GAPDH & GCTCTCTGCTCCTCCCTGTTCT/CAGGCGTCCGATACGGCCAAA & 117 & NM_017008.3 \\
$5-\mathrm{HT}_{1 \mathrm{~A}} \mathrm{R}$ & CCGCTGCGCTGATCTCGCTC/GATCGGTCTTCCGGGGTGCG & 88 & NM_012585.1 \\
$5-\mathrm{HT}_{1 \mathrm{~B}} \mathrm{R}$ & GCGAGTCTCAGACGCCCTGC/GGGTCTTGGTGGCTTTGCGCT & 71 & NM_022225.1 \\
$5-\mathrm{HT}_{1 \mathrm{D}} \mathrm{R}$ & TCACGCGGCGGCCATGATTG/CTGCCGCCAGAAGAGCGGTG & 76 & NM_012852.1 \\
$5-\mathrm{HT}_{2 \mathrm{~A}} \mathrm{R}$ & AGGCTCCTACGCAGGCCGAA/CCCAGCACCTTGCACGCCTT & 69 & NM_017254.1 \\
$5-\mathrm{HT}_{2 \mathrm{~B}} \mathrm{R}$ & AATGTCCTTGGCGGTGGCTGA/GCCAGTGGGAGGGGCCATGTA & 99 & NM_017250.1 \\
$5-\mathrm{HT}_{2 \mathrm{C}} \mathrm{R}$ & GCGATTGCAGCCGAGTCCGT/AACCCGCTAGCGTCCGGGAG & 80 & NM_012765.3 \\
\hline
\end{tabular}

FW: forward; RV: reverse; bp: base pairs; GAPDH: glyceraldehyde-3-phosphate dehydrogenase; Col1a1: type 1 collagen.

manufacturer's instructions. The ELISA plates were analyzed at $450 \mathrm{~nm}$ with a microplate reader (BioTek). The OCN concentration of each sample was calculated according to the standard curve.

\section{Detection and quantification of mineralization}

At day 15, we used Alizarin Red S (AR-S; Sigma) stain $(32,33)$ to determine the extent of mineralized matrix in the plates. In brief, cells were fixed in ice-cold $70 \%(\mathrm{v} / \mathrm{v})$ ethanol and then stained with $40 \mathrm{mM}$ AR-S, $\mathrm{pH}$ 4.2. The plates were incubated for $10 \mathrm{~min}$ at room temperature with gentle shaking. Stained monolayers were visualized by means of phase microscopy with an inverted microscope (Nikon, Japan). AR-S was released from the cell matrix by incubation in $10 \%(\mathrm{w} / \mathrm{v})$ cetylpyridinium chloride in $10 \mathrm{mM} \mathrm{Na}_{2} \mathrm{PO}_{4}, \mathrm{pH} 7.0$, for $15 \mathrm{~min}$. The released dye was transferred to a 96-well plate and assessed at $562 \mathrm{~nm}$ using a microplate reader (BioTek).

\section{Statistical analysis}

All experiments were performed in triplicate, and the data are reported as means \pm SE. Statistical analyses

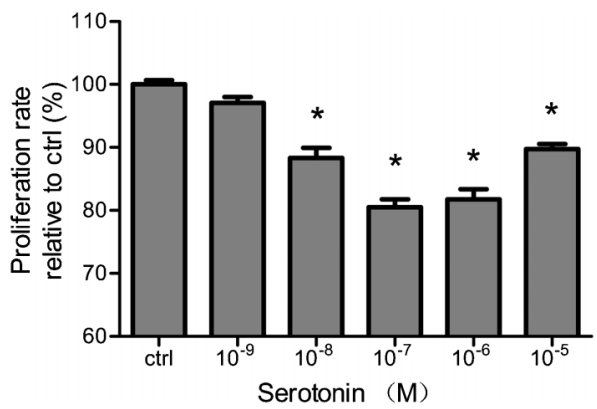

Figure 1. Serotonin inhibited proliferation of primary osteoblasts. Growth of osteoblasts treated with serotonin $(1 \mathrm{nM}-10 \mu \mathrm{M})$ was inhibited compared to controls. This influence was alleviated in the $10 \mu \mathrm{M}$ and $1 \mu \mathrm{M}$ groups (relatively high concentrations). Data are reported as means $\pm \mathrm{SE}$. ${ }^{*} \mathrm{P}<0.05$ vs control (ctrl) group (Dunnett test). were performed using the SPSS 13.0 software package (SPSS, USA). We performed one-way analysis of variance followed by the Dunnett post hoc test for multiple comparisons between groups. In all cases, $\mathrm{P}$ values less than 0.05 were considered to be statistically significant.

\section{Results}

\section{5-HT inhibited proliferation of primary osteoblasts}

Primary osteoblasts were incubated with 5-HT for 2 days, and the proliferation rate was measured as shown in Figure 1. Compared to the growth of control cells, that
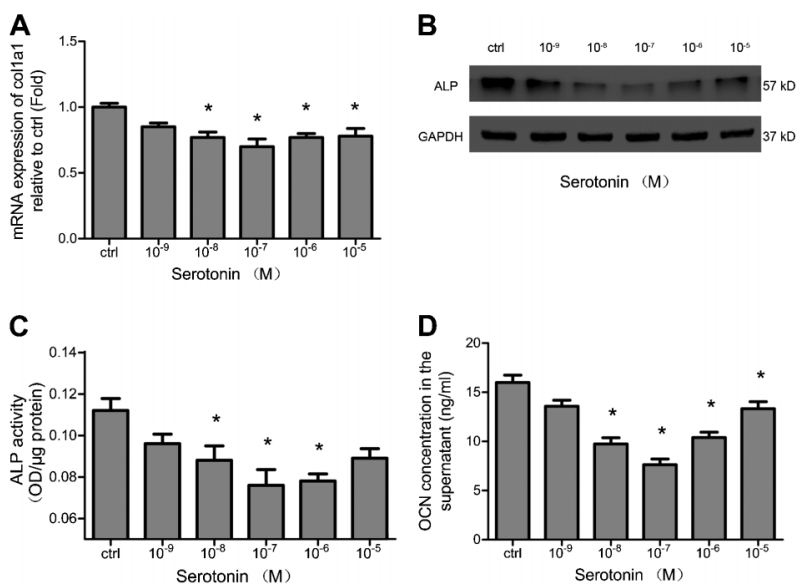

Figure 2. Serotonin affected the differentiation of primary osteoblasts. A, Real-time RT-PCR was used to evaluate the effect of different concentrations of serotonin on expression of col1a1 mRNA at day 5. Expression of col1a1 mRNA was decreased with low concentrations of serotonin, and this effect was alleviated at high concentrations. $B$, Expression pattern of ALP protein revealed by Western blot analysis in the presence of serotonin at day 10. $C$, Action of serotonin at different doses on ALP enzyme activity at day 10. D, ELISA analysis showed that at day 15 , OCN content in the cultured supernatant was reduced in serotonin groups compared with the control group. Data are reported as means \pm SE. ${ }^{*} \mathrm{P}<0.05$ vs control (ctrl) group (Dunnett test). 

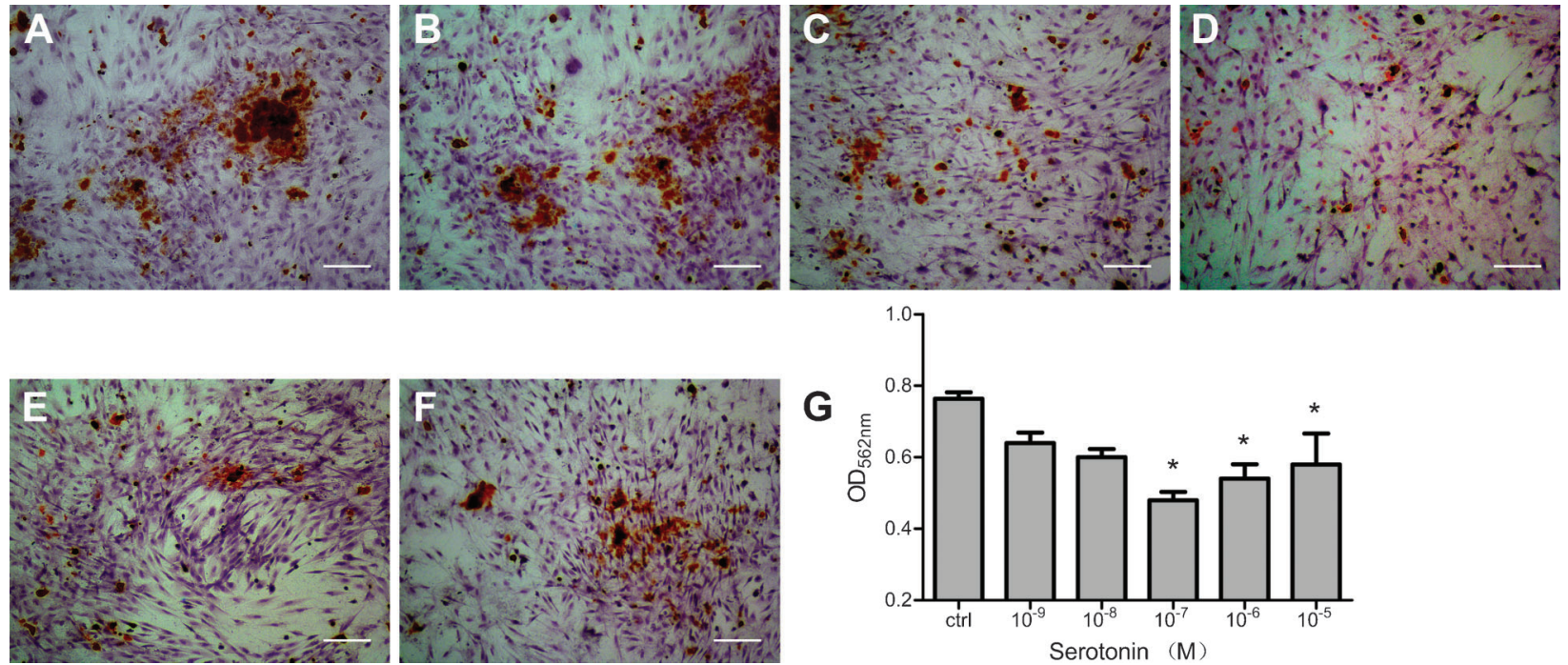

Figure 3. Serotonin suppressed mineralization of primary osteoblasts. Primary osteoblasts at passage 3 were incubated with different dosages of serotonin for 15 days and stained with Alizarin Red S. Quantitative analysis demonstrated that mineralization was suppressed in serotonin groups (G). Panels $A-F$ are representative images of the control, 1, 10, $100 \mathrm{nM}, 1$ and $10 \mu \mathrm{M}$ groups, respectively. Magnification bars: $100 \mu \mathrm{m}$. Data are reported as means $\pm \mathrm{SE} .{ }^{*} \mathrm{P}<0.05$ vs control (ctrl) group (Dunnett test).

of osteoblasts treated with 5-HT was inhibited. The inhibitory effect increased gradually in a dose-dependent manner as the 5-HT concentration increased (1-100 nM), but this effect was alleviated in the $10 \mu \mathrm{M}$ and $1 \mu \mathrm{M}$ groups (relatively high concentrations) and a reverse trend was shown.

\section{5-HT affected the differentiation of primary osteoblasts}

The effect of 5-HT on osteoblast differentiation was determined by measuring the expression of col1a1 mRNA, ALP, and OCN proteins after exposure to 5-HTcontaining media. Expression of col1a1 mRNA was significantly reduced $(\mathrm{P}<0.05)$ by the addition of $10 \mathrm{nM}$ to $10 \mu \mathrm{M} 5-\mathrm{HT}$. The $100 \mathrm{nM} 5-\mathrm{HT}$ group had the lowest levels of col1a1 gene expression (Figure 2A).

Activity of ALP, a marker of bone formation, and expression of ALP protein were measured to assess the effect of 5-HT on osteoblast differentiation. ALP was expressed in osteoblasts during long-term cultivation, with maximum expression at day 10. ALP protein expression of the experimental groups $(\sim 1-100 \mathrm{nM})$ decreased gradually, and $100 \mathrm{nM} 5-\mathrm{HT}$ reduced protein expression most significantly $(P<0.05)$. However, this inhibitory effect was attenuated when the concentration reached $\sim 1-10 \mu \mathrm{M}$ (Figure 2B). ALP enzyme activity (Figure 2C) in all groups showed a pattern that was similar to ALP protein expression.

OCN was expressed at a later stage of osteoblast differentiation and represented the beginning of bone matrix mineralization. We found that OCN content in the cultured supernatant of all groups, which reflects the amount of OCN synthesis of the osteoblasts, showed a "V" pattern, with the lowest level in the $100 \mathrm{nM}$ group (Figure 2D). Interestingly, neither immunofluorescence nor Western blot analysis detected OCN protein expression in the osteoblasts (data not shown).

\section{5-HT suppressed mineralization of primary osteoblasts}

The effects of 5-HT on osteoblast mineralization were investigated at day 15 by using AR-S staining, which identifies calcium content within the bone matrix Decreased mineralization relative to controls was observed in cultures treated with 5-HT (Figure 3). Mineralized nodule formation was reduced in all groups of 5-HT-treated osteoblasts, but this finding was statistically significant only at $100 \mathrm{nM}$ to $10 \mu \mathrm{M} 5-\mathrm{HT}(\mathrm{P}<0.05)$. Interestingly, the inhibitory effect rebounded with the increase in concentration from $1 \mu \mathrm{M}$ to $10 \mu \mathrm{M} 5-\mathrm{HT}$ similar to the pattern observed in results of proliferation and differentiation assays.

\section{5-HT receptor mRNA in primary osteoblasts}

Next, we detected which 5-HT receptor subtypes were expressed in rat primary osteoblasts. We harvested cells from the control group at days 5 and 15 to assess the relative mRNA expression of $5-\mathrm{HT}_{1 \mathrm{~A}}, 5-\mathrm{HT}_{1 \mathrm{~B}}, 5-\mathrm{HT}_{1 \mathrm{D}}$, $5-\mathrm{HT}_{2 \mathrm{~A}}, 5-\mathrm{HT}_{2 \mathrm{~B}}$, and $5-\mathrm{HT}_{2} \mathrm{C}$, which are reported to exist in bones $(19,20,25)$. Our results indicated that all six subtypes of 5-HT receptors were present in rat osteoblasts, as shown in Figure 4. Of these, $5-\mathrm{HT}_{1 \mathrm{~B}}$ and $5-\mathrm{HT}_{2 \mathrm{~A}}$ had the highest expression, at both early and late stages of osteoblast differentiation. Electrophoresis on agarose/ 

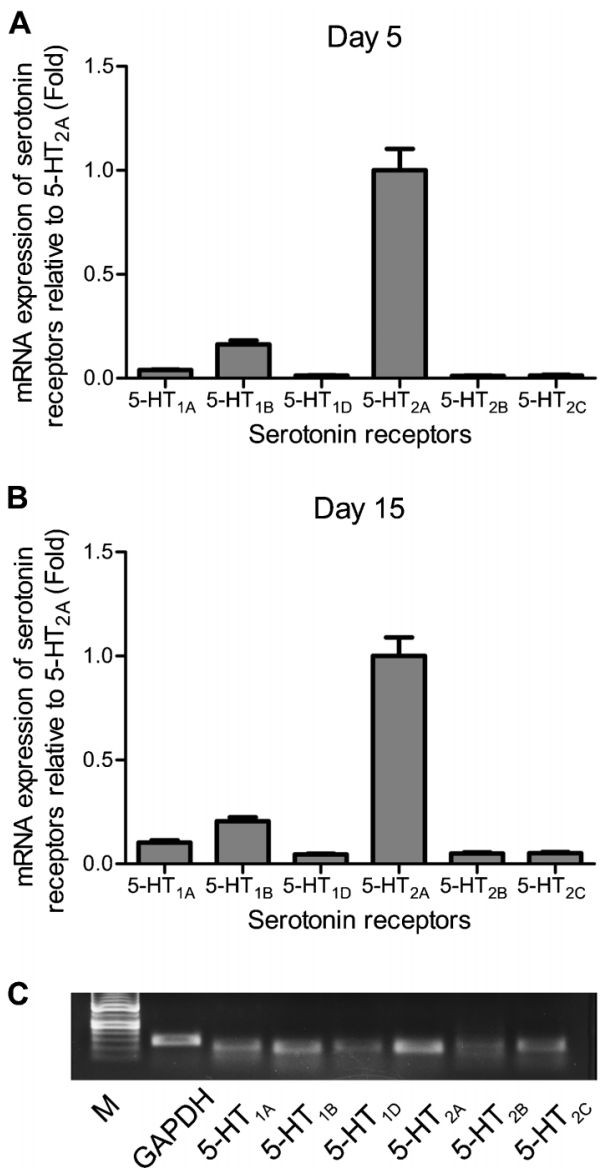

Figure 4. Expression profiles of 5-HT receptors in primary osteoblasts. Cells from the control group were harvested at day $5(A)$ and day $15(B)$ to assess the relative levels of mRNA expression of $5-\mathrm{HT}_{1 \mathrm{~A}}, 5-\mathrm{HT}_{1 \mathrm{~B}}, 5-\mathrm{HT}_{1 \mathrm{D}}, 5-\mathrm{HT}_{2 \mathrm{~A}}, 5-\mathrm{HT}_{2 \mathrm{~B}}$, and $5-\mathrm{HT}_{2 \mathrm{C}}$ receptors. Electrophoresis on agarose/TAE gel further confirmed the presence of $5-\mathrm{HT}$ receptors and amplification specificity $(C)$. M: marker; GAPDH: glyceraldehyde-3-phosphate dehydrogenase.

TAE gel further confirmed the presence of 5-HT receptors (Figure 4C).

\section{Discussion}

Our preliminary experiment characterized the differentiation of rat primary osteoblast cultures. Changes in ALP activity and differential gene expression characterize the following three distinct stages (34): growth (proliferation), up to 5-6 days; matrix maturation (or differentiation), up to 10-11 days; and mineralization, up to 15-16 days. Each of the three osteoblast-specific proteins that we analyzed reaches peak expression during a different stage (34), which explains why we detected col1a1 at day 5, ALP at day 10 , and OCN at day 15 . Because there is a significant effect of cell density on the rate of osteoblast proliferation and differentiation, cytometry was used to ensure that the number of cells in each group was equal.

Our results showed that $5-\mathrm{HT}$ at low concentrations resulted in a decrease in the proliferation rate of rat osteoblasts in a dose-dependent manner (in low-dosage groups). The presented results are consistent with, and also contradictory to, those of some previous studies. Our results were similar to those reported by Yadav et al. (20). They found that proliferation of wild-type osteoblasts decreased when they were treated with $5-\mathrm{HT}$ for $24 \mathrm{~h}$.

Col1a1, ALP, and OCN, all synthesized by osteoblasts, are important components of the extracellular matrix and are indispensable for the onset of mineralization and bone formation. Therefore, the expression levels of these three proteins could reflect, to a large extent, the ability of osteoblasts to generate bones. Our results indicated that the addition of 5-HT did affect their expression profiles as well as the mineralization capability of osteoblasts. The dominant effect was inhibitory, especially in low-dosage 5-HT groups. However, 5-HT has also been reported to decrease expression of CycD1, CycD2, and CycE1 without affecting expression of col1a1 or of other genes characteristic of the osteoblast phenotype (20).

However, at relatively high concentrations, this inhibition effect was significantly attenuated, and showed a trend to promote the proliferation and function of osteoblasts. In order to clarify this strange phenomenon, we next tried to detect which 5-HT receptor subtypes were expressed in rat primary osteoblasts, because the activation of different 5 -HT receptors might cause different effects on osteoblasts.

We found all six of the 5-HT receptor subtypes (5$\mathrm{HT}_{1 \mathrm{~A}}, 5-\mathrm{HT}_{1 \mathrm{~B}}, 5-\mathrm{HT}_{1 \mathrm{D}}, 5-\mathrm{HT}_{2 \mathrm{~A}}, 5-\mathrm{HT}_{2 \mathrm{~B}}$, and 5- $\mathrm{HT}_{2 \mathrm{C}}$ ) were found in rat osteoblasts. Of these, $5-\mathrm{HT}_{2 \mathrm{~A}}$ and $5-\mathrm{HT}_{1 \mathrm{~B}}$ receptors had the highest expression levels, at both early and late stages of differentiation. Consistent with our findings in rats, 5- $\mathrm{HT}$ receptors, including $5-\mathrm{HT}_{1 \mathrm{~A}}, 5-\mathrm{HT}_{1 \mathrm{~B}}$, $5-\mathrm{HT}_{1 \mathrm{D}}, 5-\mathrm{HT}_{2 \mathrm{~A}}, 5-\mathrm{HT}_{2 \mathrm{~B}}$, and $5-\mathrm{HT}_{2 \mathrm{C}}$, have been reported to be widely distributed in murine tissues $(20,35)$. It has been reported that $5-\mathrm{HT}$ promotes the growth of cells of various origins via the $5-\mathrm{HT}_{2 \mathrm{~A}}$ receptor $(36,37)$. Expression of $5-\mathrm{HT}_{2 \mathrm{~B}}$ receptor mRNA was demonstrated in fetal chicken bone cells (19). Occupancy of the $5-\mathrm{HT}_{2 \mathrm{~B}}$ receptor pharmacologically stimulated the proliferation of periosteal fibroblasts (19). 5-HT may also facilitate osteoblast proliferation and differentiation, via the 5$\mathrm{HT}_{2 \mathrm{~B}}$ receptor (22). Yadav and colleagues (20) have demonstrated that, among the known 5-HT receptors, only three are significantly expressed in osteoblasts: $5-\mathrm{HT}_{1 \mathrm{~B}}$ (the most highly expressed), $5-\mathrm{HT}_{2 \mathrm{~A}}$, and $5-\mathrm{HT}_{2 \mathrm{~B}}$. Subsequently, they confirmed that only the $5-\mathrm{HT}_{1 \mathrm{~B}}$ receptor was functional in osteoblasts and was critical to the signal transduction of 5- HT. 5- HT bound to the 5- $\mathrm{HT}_{1 \mathrm{~B}}$ receptor caused a decrease in cyclin expression and osteoblast proliferation (20). 
Based on the observations of these researchers and our data that $5-\mathrm{HT}_{1 \mathrm{~B}}$ and $5-\mathrm{HT}_{2 \mathrm{~A}} 5-\mathrm{HT}$ receptor subtypes were primarily detected in osteoblasts in our experiments, we speculate that the cause of dual effects of 5-HT on bone metabolism may rely on the activation of different receptor subtypes. The $5-\mathrm{HT}_{1 \mathrm{~B}}$ receptor belongs to the $\mathrm{G} \alpha \mathrm{i}$-protein coupled receptor (GPCR) and suppresses the activity of cAMP protein kinase $A(P K A)$ after activation, thereby inhibiting bone formation (20). Meanwhile, the inhibition of PKA leads to phosphorylation of activating transcription factor 4, stimulating the differentiation of osteoclasts (38). However, the $5-\mathrm{HT}_{2 \mathrm{~A} / \mathrm{B}}$ receptor belongs to the $\mathrm{G} \alpha \mathrm{q} / 11$ GPCR, which transducts signals through the phospholipase C-inositol phosphate 3/diacylglycerol-protein kinase C (PLC-IP3/DAG-PKC) signaling pathway. Activation of this signaling pathway can promote the proliferation of osteoblasts and promote bone formation (24).

The signaling pathways of $5-\mathrm{HT}_{1 \mathrm{~B}}$ and $5-\mathrm{HT}_{2 \mathrm{~A} / \mathrm{B}}$ receptor subtypes are remarkably similar to those of the parathyroid hormone (PTH) receptor PTH1R. PTH1R, which also belongs to GPCR, regulates osteoblast proliferation, differentiation, and function through the CAMP-PKA and PLC-IP3/DAG-PKC signaling pathways (39). PTH can produce both anabolic and catabolic effects by activating different signaling pathways, depending on its administration method. PTH, at relatively high concentrations, is required for efficient activation of the PLC-PKC pathway; this is in contrast to activation of the cAMP-PKA pathway, which occurs at low concentrations in the same cell host (39).

Given all that, we speculate that $5-\mathrm{HT}$ at low concentrations activates the $5-\mathrm{HT}_{1 \mathrm{~B}}$ receptor, which leads to the antiproliferation of osteoblasts. At relatively high concentrations, it may activate the $5-\mathrm{HT}_{2 \mathrm{~A} / \mathrm{B}}$ receptor, resulting in osteoblast proliferation. Because osteoblast

\section{References}

1. Anastasilakis AD, Polyzos SA, Delaroudis S, Bisbinas I, Sakellariou GT, Gkiomisi A, et al. The role of cytokines and adipocytokines in zoledronate-induced acute phase reaction in postmenopausal women with low bone mass. Clin Endocrinol 2012; 77: 816-822, doi: 10.1111/j.1365-2265.2012.04459.x.

2. Cutler GB Jr. The role of estrogen in bone growth and maturation during childhood and adolescence. J Steroid Biochem Mol Biol 1997; 61: 141-144, doi: 10.1016/S09600760(97)80005-2.

3. Somjen D. Vitamin D modulation of the activity of estrogenic compounds in bone cells in vitro and in vivo. Crit Rev Eukaryot Gene Expr 2007; 17: 115-147, doi: 10.1615/ CritRevEukarGeneExpr.v17.i2.30.

4. Vescini F, Grimaldi F. PTH 1-84: bone rebuilding as a target for the therapy of severe osteoporosis. Clin Cases Miner Bone Metab 2012; 9: 31-36.

5. Vaswani M, Linda FK, Ramesh S. Role of selective serotonin reuptake inhibitors in psychiatric disorders: a comprehensive review. Prog Neuropsychopharmacol Biol number and cell viability at the end of the growth period will have a sustained impact on the subsequent differentiation progress, the effects of $5-\mathrm{HT}$ on osteoblast differentiation and mineralization might also be secondary to its proliferation-regulating effect. This might explain the dual and perplexing effects of 5-HT on osteoblast proliferation and function. Additionally, GPCRs are well known for their ability to become desensitized upon exposure to excess ligand. 5-HT at concentrations of 1-10 $\mu \mathrm{M}$ might have led to the desensitization of $5-\mathrm{HT}_{2 \mathrm{~A}}$ and $5-\mathrm{HT}_{1 \mathrm{~B}}$ receptors, which might also be the cause of this phenomenon. To elucidate this mechanism, further studies are warranted, and selective agonists and antagonists specific to 5-HT receptor subtypes will be required, as well as an analysis of receptor-binding activities of each receptor subtype.

In summary, our study confirmed that 5-HT could impair the proliferation of osteoblasts at low concentrations, leading to decreased differentiation and matrix deposition. However, at high concentrations, this inhibition was significantly attenuated, and showed a trend to promote bone formation. The receptors $5-\mathrm{HT}_{1 \mathrm{~A}}, 5-\mathrm{HT}_{1 \mathrm{~B}}, 5-\mathrm{HT}_{1 \mathrm{D}}, 5-$ $\mathrm{HT}_{2 \mathrm{~A}}, 5-\mathrm{HT}_{2 \mathrm{~B}}$, and $5-\mathrm{HT}_{2 \mathrm{C}}$ were all present at early and late stages of osteoblast differentiation, while receptors $5-\mathrm{HT}_{2 \mathrm{~A}}$ and $5-\mathrm{HT}_{1 \mathrm{~B}}$ were most expressed. These data suggest that $5-\mathrm{HT}$ plays a significant role in the modulation of bone metabolism. The cause for the dual effects of 5-HT on bone metabolism may rely on the different signaling pathways of these two receptor subtypes.

\section{Acknowledgments}

Research supported by a grant from the National Natural Science Foundation of China to L.P. Yu (\#30600626).
Psychiatry 2003; 27: 85-102, doi: 10.1016/S02785846(02)00338-X.

6. Ambrosini PJ. A review of pharmacotherapy of major depression in children and adolescents. Psychiatr Serv 2000; 51: 627-633, doi: 10.1176/appi.ps.51.5.627.

7. Kastelic EA, Labellarte MJ, Riddle MA. Selective serotonin reuptake inhibitors for children and adolescents. Curr Psychiatry Rep 2000; 2: 117-123, doi: 10.1007/s11920000-0055-x.

8. Ryan ND. Medication treatment for depression in children and adolescents. CNS Spectr 2003; 8: 283-287.

9. Bolton JM, Metge C, Lix L, Prior H, Sareen J, Leslie WD. Fracture risk from psychotropic medications: a populationbased analysis. J Clin Psychopharmacol 2008; 28: 384-391, doi: 10.1097/JCP.0b013e31817d5943.

10. Calarge CA, Zimmerman B, Xie D, Kuperman S, Schlechte JA. A cross-sectional evaluation of the effect of risperidone and selective serotonin reuptake inhibitors on bone mineral density in boys. J Clin Psychiatry 2010; 71: 338-347, doi: 
10.4088/JCP.08m04595gre

11. Diem SJ, Blackwell TL, Stone KL, Yaffe K, Haney EM, Bliziotes MM, et al. Use of antidepressants and rates of hip bone loss in older women: the study of osteoporotic fractures. Arch Intern Med 2007; 167: 1240-1245, doi: 10.1001/archinte.167.12.1240.

12. Lewis CE, Ewing SK, Taylor BC, Shikany JM, Fink HA, Ensrud KE, et al. Predictors of non-spine fracture in elderly men: the MrOS study. J Bone Miner Res 2007; 22: 211-219, doi: $10.1359 / \mathrm{jbmr} .061017$.

13. Liu B, Anderson G, Mittmann N, To T, Axcell T, Shear N. Use of selective serotonin-reuptake inhibitors or tricyclic antidepressants and risk of hip fractures in elderly people. Lancet 1998; 351: 1303-1307, doi: 10.1016/S0140-6736(97)09528-7.

14. Richards JB, Papaioannou A, Adachi JD, Joseph L, Whitson $\mathrm{HE}$, Prior JC, et al. Effect of selective serotonin reuptake inhibitors on the risk of fracture. Arch Intern Med 2007; 167: 188-194, doi: 10.1001/archinte.167.2.188.

15. Vestergaard P, Rejnmark L, Mosekilde L. Selective serotonin reuptake inhibitors and other antidepressants and risk of fracture. Calcif Tissue Int 2008; 82: 92-101, doi: 10.1007/s00223-007-9099-9.

16. Ziere G, Dieleman JP, van der Cammen TJ, Hofman A, Pols $\mathrm{HA}$, Stricker BH. Selective serotonin reuptake inhibiting antidepressants are associated with an increased risk of nonvertebral fractures. J Clin Psychopharmacol 2008; 28 : 411-417, doi: 10.1097/JCP.0b013e31817e0ecb.

17. Battaglino R, Fu J, Spate U, Ersoy U, Joe M, Sedaghat L, et al. Serotonin regulates osteoclast differentiation through its transporter. J Bone Miner Res 2004; 19: 1420-1431, doi: 10.1359/JBMR.040606.

18. Bliziotes MM, Eshleman AJ, Zhang XW, Wiren KM. Neurotransmitter action in osteoblasts: expression of a functional system for serotonin receptor activation and reuptake. Bone 2001; 29: 477-486, doi: 10.1016/S87563282(01)00593-2.

19. Westbroek I, van der Plas A, de Rooij KE, Klein-Nulend J, Nijweide PJ. Expression of serotonin receptors in bone. J Biol Chem 2001; 276: 28961-28968, doi: 10.1074/ jbc.M101824200.

20. Yadav VK, Ryu JH, Suda N, Tanaka KF, Gingrich JA, Schutz G, et al. Lrp5 controls bone formation by inhibiting serotonin synthesis in the duodenum. Cell 2008; 135: 825837, doi: 10.1016/j.cell.2008.09.059.

21. Baudry A, Bitard J, Mouillet-Richard S, Locker M, Poliard A, Launay JM, et al. Serotonergic $5-\mathrm{HT}(2 \mathrm{~B})$ receptor controls tissue-nonspecific alkaline phosphatase activity in osteoblasts via eicosanoids and phosphatidylinositol-specific phospholipase C. J Biol Chem 2010; 285: 26066-26073, doi: 10.1074/jbc.M109.073791.

22. Collet C, Schiltz C, Geoffroy V, Maroteaux L, Launay JM, de Vernejoul MC. The serotonin 5-HT2B receptor controls bone mass via osteoblast recruitment and proliferation. FASEB J 2008; 22: 418-427, doi: 10.1096/fj.07-9209com.

23. Cui $\mathrm{Y}$, Niziolek PJ, MacDonald BT, Zylstra CR, Alenina N, Robinson DR, et al. Lrp5 functions in bone to regulate bone mass. Nat Med 2011; 17: 684-691, doi: 10.1038/nm.2388.

24. Gustafsson BI, Westbroek I, Waarsing JH, Waldum $\mathrm{H}$, Solligard $E$, Brunsvik $A$, et al. Long-term serotonin administration leads to higher bone mineral density, affects bone architecture, and leads to higher femoral bone stiffness in rats.
J Cell Biochem 2006; 97: 1283-1291, doi: 10.1002/jcb.20733

25. Hirai $T$, Tokumo $K$, Tsuchiya $D$, Nishio $H$. Expression of mRNA for 5-HT2 receptors and proteins related to inactivation of 5-HT in mouse osteoblasts. J Pharmacol Sci 2009; 109: 319-323, doi: 10.1254/jphs.08243SC.

26. Locker M, Bitard J, Collet C, Poliard A, Mutel V, Launay JM, et al. Stepwise control of osteogenic differentiation by 5 HT(2B) receptor signaling: nitric oxide production and phospholipase A2 activation. Cell Signal 2006; 18: 628639, doi: 10.1016/j.cellsig.2005.06.006.

27. Modder UI, Achenbach SJ, Amin S, Riggs BL, Melton LJ III, Khosla S. Relation of serum serotonin levels to bone density and structural parameters in women. $J$ Bone Miner Res 2010; 25: 415-422, doi: 10.1359/jbmr.090721.

28. Yin Z, Chen X, Chen JL, Shen WL, Hieu Nguyen TM, Gao L, et al. The regulation of tendon stem cell differentiation by the alignment of nanofibers. Biomaterials 2010; 31: 2163-2175, doi: 10.1016/j.biomaterials.2009.11.083.

29. Schmittgen TD, Zakrajsek BA. Effect of experimental treatment on housekeeping gene expression: validation by real-time, quantitative RT-PCR. J Biochem Biophys Methods 2000; 46: 69-81, doi: 10.1016/S0165-022X(00) 00129-9.

30. Bliziotes $M$, Eshleman A, Burt-Pichat B, Zhang XW, Hashimoto J, Wiren K, et al. Serotonin transporter and receptor expression in osteocytic MLO-Y4 cells. Bone 2006; 39: 1313-1321, doi: 10.1016/j.bone.2006.06.009.

31. Nakano Y. Novel function of DUSP14/MKP6 (dual specific phosphatase 14) as a nonspecific regulatory molecule for delayed-type hypersensitivity. $\mathrm{Br} J$ Dermatol 2007; 156: 848-860, doi: 10.1111/j.1365-2133.2006.07708.x.

32. Maeda T, Kawane T, Horiuchi N. Statins augment vascular endothelial growth factor expression in osteoblastic cells via inhibition of protein prenylation. Endocrinology 2003; 144: 681-692, doi: 10.1210/en.2002-220682.

33. Maeda T, Matsunuma A, Kawane T, Horiuchi N. Simvastatin promotes osteoblast differentiation and mineralization in MC3T3-E1 cells. Biochem Biophys Res Commun 2001; 280: 874-877, doi: 10.1006/bbrc.2000.4232.

34. Lian JB, Stein GS. Concepts of osteoblast growth and differentiation: basis for modulation of bone cell development and tissue formation. Crit Rev Oral Biol Med 1992; 3: 269-305.

35. Lauder JM, Wilkie MB, Wu C, Singh S. Expression of 5$\mathrm{HT}(2 \mathrm{~A}), 5-\mathrm{HT}(2 \mathrm{~B})$ and $5-\mathrm{HT}(2 \mathrm{C})$ receptors in the mouse embryo. Int J Dev Neurosci 2000; 18: 653-662, doi: 10.1016/S0736-5748(00)00032-0.

36. Pakala R, Willerson JT, Benedict CR. Mitogenic effect of serotonin on vascular endothelial cells. Circulation 1994; 90: 1919-1926, doi: 10.1161/01.CIR.90.4.1919.

37. Stroebel M, Goppelt-Struebe M. Signal transduction pathways responsible for serotonin-mediated prostaglandin $\mathrm{G} / \mathrm{H}$ synthase expression in rat mesangial cells. J Biol Chem 1994; 269: 22952-22957.

38. Kode A, Mosialou I, Silva BC, Rached MT, Zhou B, Wang J, et al. FOXO1 orchestrates the bone-suppressing function of gut-derived serotonin. J Clin Invest 2012; 122: 3490-3503, doi: $10.1172 / \mathrm{JCl} 64906$

39. Datta NS, Abou-Samra AB. PTH and PTHrP signaling in osteoblasts. Cell Signal 2009; 21: 1245-1254, doi: 10.1016/ j.cellsig.2009.02.012. 